BENM 2021

International Scientific and Practical Conference "Biotechnology, Ecology, Nature Management"

\title{
ROLE OF SMALL ARCHITECTURAL STRUCTURES IN THE ORGANIZATION OF URBAN OPEN PUBLIC
}

\author{
V. A. Kurochkina (a)*, V. A. Klimov (b), M. O. Belova (c), E. K. Kalinichenko (c) \\ *Corresponding author
}

(a) National Research Moscow State University of Civil Engineering, Russia, kurochkina.mgsu.ru@yandex.ru

(b) National Research Moscow State University of Civil Engineering, Russia

(c) National Research Moscow State University of Civil Engineering, Russia

\begin{abstract}
Nowadays the perspective of design and development of public spaces is one of the most popular universal trends in the sphere of city planning. It is connected with the fact, that public spaces form the city's "face", providing its uniqueness and being responsible for the creation of a harmonious uniform image of the megalopolis. At the same time, it is possible to use not only such traditional and already developed elements as streets, squares, parks, squares, boulevards and embankments for forming the public spaces, but also the elements, which can be conditionally called "alternative", which can include terraces, arbour, rest areas with different functions, auto-movie theatres, the open scenic areas and others. The role of small architectural structures in forming of public open spaces is studied in this article. The reasons of their emergence and the history of their forming during various historical stages are considered on the example of the small architectural constructions presented in the form of arbour and terraces as well as their groups. The principles and arrangement of those arbour are proved; several options of arbour are also offered, depending on their functionality on the example of the park Northern Tushino.
\end{abstract}

2672-8575 @ 2022 Published by European Publisher.

Keywords: Landscape and park architecture, open public spaces, small architectural structure, urban public space, urbanized territories 


\section{Introduction}

Public spaces are the places of concentration of the city life, they represent the way of life of people in the specific city. The image of the city in general depends on from their appearance, their proper scale for a human, the quality of architecture and fullness various social practics (Kurochkina, 2020a).

As a rule, vigorous activity of people concentrates in the cities centres which attractiveness defines the image of these territories in many respects. Proceeding from it, it is important to keep already developed features of the environment in historical parts of the centres of the cities, and to develop the concept of building allowing to create the memorable unique atmosphere for again planned territories; and at the same time, to have made the space brisk and often visited (Kurochkina, 2020b). It is possible to achieve these objectives by the means of the thought-over functional improvement and the organization of public spaces (Kurochkina, 2020c, 2020d)

Improvement and organization of the city public spaces is the set of actions, including the development of the concept on their arrangement, architectural appearance and construction. At the same time, the development of the whole city space has to submit to the principle of the sustainable development, meant to improve the quality of the environment (which is closely connected with the citizens health) and to increase comfort and safety of inhabitants. That can be also reached at the expense inclusion of "alternative" elements of the city public spaces into the urban and park environment, including small architectural forms, which also have to submit to the modern rules of forming of public spaces; namely they have to be the part of the architectural and landscape complex, to fit into the environment harmoniously, performing the functions, allocated for them.

Gazebos, used for expressiveness and functional organization of spaces, act as one of the examples of the use of small architectural forms during planning and improvement of the territories.

The arbor is defined is a light construction, intended for rest and conversation, that is the origin of the name. It includes benches and a roof, sometimes a table; it is located in gardens and parks.

The first arbour appeared in Ancient Egypt (figure 1) about 5000 years ago. An arbour, as well as any architectural structure, has to have three important components: beauty, durability and functionality.

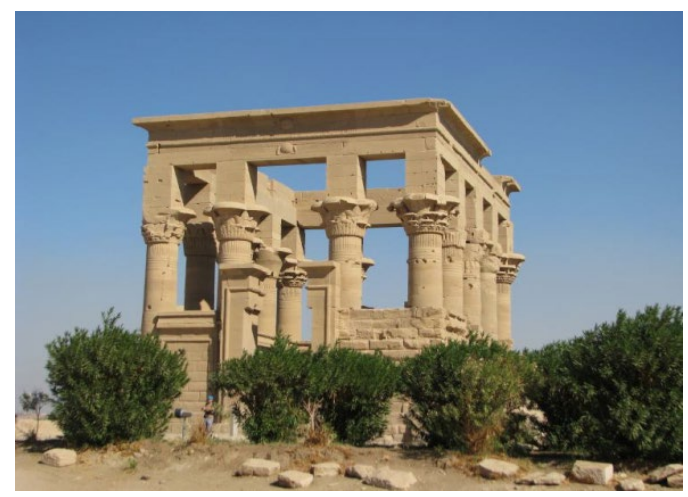

Figure 1. Ancient gazebo of Egypt (The ancient gazebo of Egypt, 2018) 
As it was already noted, gazebos initially performed several functions. Over time their functions extended, became more complex, some gazebos became architectural monuments which are protected by the state and are not intended for year-round visit and rest.

\section{Problem Statement}

The problem of small architectural structures in the organization of the city open public spaces coherent with their shortage or ill-considered placement, or the shortage of their quantity, was considered on the example of the Northern Tushino park which is located in the territory of the municipal district Northern Tushino in the Northwest of Moscow (figure 2). The population of the district is 165,736 people, and the area is 9.4 sq. $\mathrm{km}$.

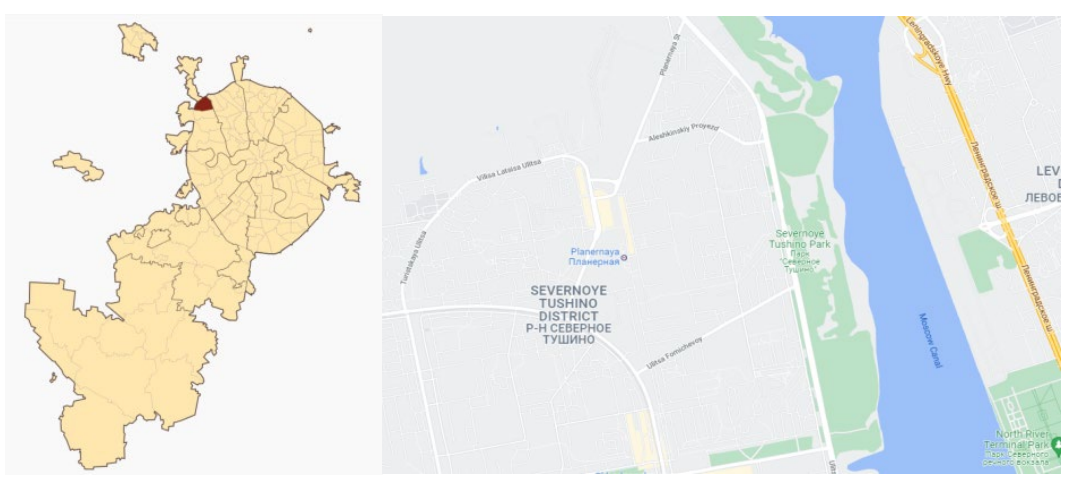

Figure 2. Scheme of Moscow is on the left (Scheme of Moscow, 2021), schematic map of a part of the Severnoye Tushino district with a park is on the right side (Mapdiagram of a part of the SevernoyeTushino district with a park, 2021)

The Northern Tushino park created in 1992, is one of the youngest parks in Moscow. The park is in the structure of especially protected area of the natural-and-historical Tushino park" that can be seen in figure 3.

Tushinsky Nature and Historical park

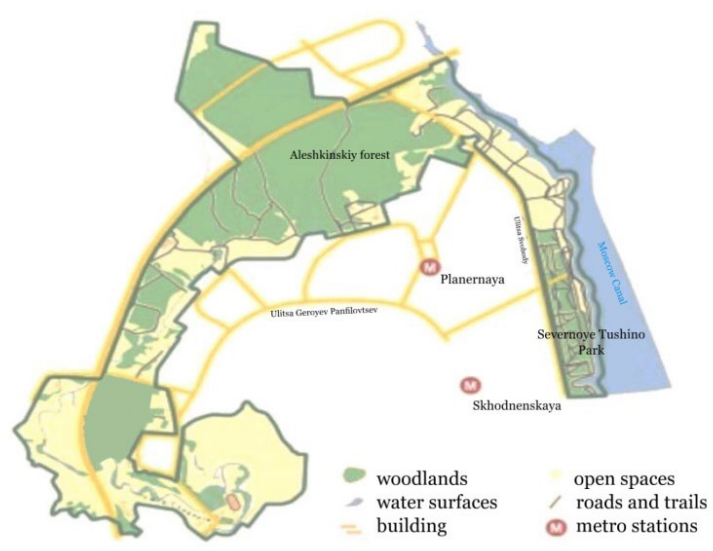

Figure 3. Scheme of the Tushinsky Nature and Historical park (Scheme of the naturalhistorical park "Tushinsky", 2021) 
The territory of the park is located along the Khimki reservoir opposite to the Northern river station and port, its extent is $2.5 \mathrm{~km}$ and its width is about $300 \mathrm{~m}$. The area of the park is 69.2 hectares.

Nowadays the problem of insufficient improvement of the territory which is shown in the shortcoming of the quantity of necessary vacation spots is observed in the park. Therefore, people arrange rest in the most improper places despite the bans and the threatening penalties. The fires in the green space, pollution of territories can be the consequence of that and there can be also a damage of lawns, bushes, trees (figure 4).

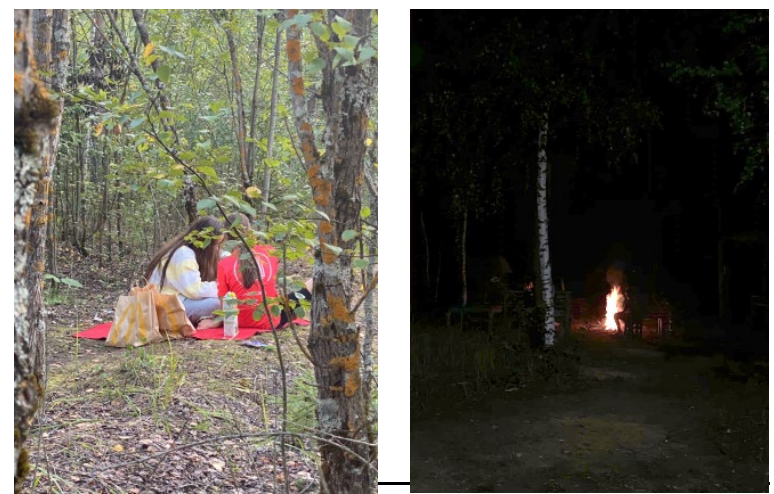

Figure 4. Damage of lawns, bushes, trees

The following tasks are set in this work:

- to investigate the perspective,

- to define criteria, which can be the basis to define the location of gazebos and their sizes,

- to develop the concept of the territories improvement with the use of small architectural forms,

- to offer the project of gazebos depending on their functionality.

\section{The Study Purpose}

There are several types of gazebos. Rotunda is one of them; it is a gazebo of round shape which often looks as the columns, located around and supporting the roof (figure 5).

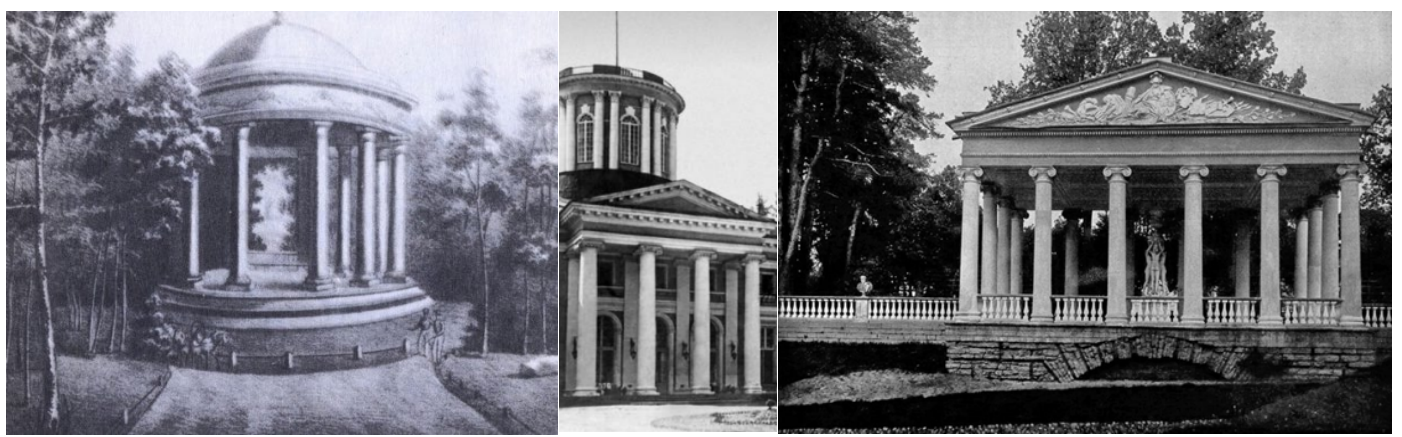

Figure 5. On the left is a gazebo-rotunda (Gazebo-rotunda, 2021), in the middle is the belvedere of the palace in Arkhangelsk (Belvedere Palace in Arkhangelsk, 2021), on the right is the pavilion of the Three graces (Pavilion of the Three Graces, 2021) 
A small isolated construction is called a pavilion. One of examples is provided in figure 5; that is the pavilion of the Three graces. Unlike an arbor the pavilion is closed from atmospheric actions from all the directions. Light construction on the height from where the view of nearby vicinities opens, is names a belvedere. It can be a separate construction, or a bulkhead on the building.

Earlier mainly natural materials were applied for the construction of gazebos: stone, hewn marble. Wood was used less often. As for the homeland of gazebos, Egypt, it is possible to note that the process of construction of such structures was labor-consuming then: slaves carried stones on backs or on vehicles.

In Ancient Russia wooden architecture was important among the other crafts. Therefore, gazebos were built of wood here. Such gazebos were not expensive, as the large space of the country was occupied by the forests. Often the gazebos were decorated with carved elements, rail-posts and platbands. But at the same time, there were no ready gazebos at once, they were built independently, or ordered from masters. In the 13th century rotunda won popularity, and the Russian nobility and princes often installed them in their yards.

Now glued bar, pack (chopped gazebos), joiner's board and profile bar are applied for the production of gazebos. It is possible to refer to the main features of are applied for the production of gazebos, such as spaciousness, rather small sizes, low cost, beautiful view and variety of forms and designs.

Gazebos have various arrangement, appearance, forms and materials, used for their construction. The simplest type is the four-columns gazebo covered with a straight line or a four-pitched roof. Besides, gazebos can be polygonal or round. Sometimes they are done absolutely open, in the form of the small site which is densely surrounded with trees or enclosed with a three-leaved trellis, the wooden or wire lattice, covered with climbing plants. However, gazebos become not only opened, but they can be also closed, with walls, windows and doors.

Nowadays they are made of wood, iron and natural stone. In the first case they are in the Russian, Swiss or Chinese style; in the latter case they are of more monumental character and have the forms of ancient classical styles, Greek and Roman or the forms of the Renaissance style. The roof of a gazebo can be topped with a weather vane or a small sculpture. Sometimes internal or external lighting is brought up to the gazebos, however, the that is more popular for the closed gazebos.

There is a set of classifications of gazebos: according their functionality, size, capacity, form and location (land, located near the water, island and water) and so forth.

The research purpose is studying of this subject since the beginning of history of emergence of small architectural forms on the example of gazebos, tracking their modernizations eventually and also to offer possible options on their integration into the environment.

The research purposes also include the analysis of functionality of gazebos, search of the optimal variant of forming of public space in the conditions of dense urban development with historical monuments of architecture and city planning as well as the placement of gazebos, according to the concept of improvement of the territory, developed by us on the example of the park Northern Tushino. 


\section{Research Methods}

According to methodical recommendations (Mel, 2017) the elements of improvement include:

- gardening elements;

- coverings;

- protections (fences);

- street communal-and-household and technical equipment;

- gaming and sports equipment;

- lighting elements;

- small architectural forms and city furniture;

- non-capital non-stationary structures.

When developing the concept of the territories improvement, it is possible to proceed from the most various principles. One of such principles is obviously the maximum involvement of inhabitants in the process on improvement of the territory where they live, taking into account their requirements and requests (as well as other participants of activities for improvement) with their direct participation at all stages of the concept creation. When developing the concept, it is also necessary to consider strategic problems of complex sustainable development of the urban environment, communication and interaction of certain citizens and communities, their participation in the design and implementation of the projects on the territory development, the maintenance of subjects of improvement and so forth.

As for the model of sustainable development, it assumes the use of resources, so that the needs of the person would be realized not only for the present, but also for the future generations, when preserving the environment. Thus, sustainable development represents the balance of interests of a person, the economy and the nature. The model of the person (society) development, which is based only on the cost efficiency can lead to the environmental pollution and decrease in its quality. The decline in the quality of the environment leads in turn to the deterioration in human health and natural resources, and to the deterioration in economic and social development subsequently. On the contrary, the realization of the principles of sustainable development can promote the improvement of the ecological situation in the cities, when they will become a more attractive place for life and work of a person. The realization of the principles of sustainable development is also implemented in the city planning actively. The set of actions for the improvement, taking into account the modern requirements, designed to provide complex sustainable development of the urban environment is presented in table 1.

Table 1. Landscaping activities

\begin{tabular}{cc}
\hline Types of improvement & Landscaping activities \\
\hline Social improvement & - Improvement of the system of social service \\
- Level of territories improvement, availability of space distribution and availability \\
of territories of social facilities
\end{tabular}


building for work on external improvement of territories.

- Carrying out complex reconstruction of building in territories, adjacent to the rivers beds and water areas; construction, improvement and modernization of the treatment facilities systems.

- Gardening, equipping of the territory with small architectural forms and elements of improvement.

Landscape-and-climatic - Expansion of the territory of the city at the expense of recultivation of the territory improvement

(ledges, ravines) which are difficult to development.

- Improvement and gardening of embankments of the rivers, public centres and water areas, as well as the sites of parks and squares, adjoining to them.

Ecological improvement

- System of actions for ensuring protection of natural components and for providing ecological safety of the urban population.

- Providing with available and comfortable transport infrastructure.

Transport improvement - Transport availability of various public objects.

(Compiled by authors)

Planning of the city including park space has to be open and flexible, allowing to react not only on natural, expected, but also on spontaneous, sometimes unexpected changes in the city life and development of the citizens' needs. The use of convenient and clear planned targets of the development of economy and necessary demographic and social parameters is the cornerstone, is traditionally in the base of the concept of planning of territories. However, it is represented, that when developing modern planning of territories, more difficult parameters, and less certain principles of a shaping of the city (such as such climatic, ecological, architectural and art and common cultural principles) are to be considered.

These parameters are interconnected among themselves strongly. For example, climatic parameters have a considerable impact on forming of open green spaces, which in turn are a component of the ecological framework of the city.

The system of open green spaces of the city is usually considered to be an important part of the city structure, however, it is most likely desirable, than obligatory. It is also reflected by the design codes containing some quantitative parameters, for example security with the planted trees and shrubs territories, but deprived of quality characteristics of the system. However, the system of the open planted trees and shrubs spaces is not just desirable, but obligatory, indispensable part of the city structure. Such understanding of its role is caused by the aspiration to achievement of stability of a city landscape; in other words, balances of management of the person and processes of self-control of the urban environment at the expense of the natural components entering it.

Steadiness of natural and artificial, anthropogenic elements of the city means taking into account of not only quantitative, but also quality characteristics of the system of the open planted trees and shrubs spaces as the main bearer of elements of natural self-control of the city landscape. The efficiency of application of green plantings is presented in table 2 .

Table 2. Efficiency of green spaces and landscaping elements

\begin{tabular}{|c|c|c|c|c|c|c|}
\hline Parameters & $\begin{array}{c}\text { Lawn, } \\
\text { flower bed }\end{array}$ & Canopies & $\begin{array}{c}\text { Ordinary } \\
\text { planting of } \\
\text { trees }\end{array}$ & $\begin{array}{c}\text { Ordinary } \\
\text { planting of } \\
\text { trees }\end{array}$ & $\begin{array}{c}\text { Pergola } \\
\text { covered with } \\
\text { plants }\end{array}$ & Fountain \\
\hline Air temperature, $\mathrm{C}^{\circ}$ & 0.5 & & 1.5 & $1-1.5$ & $1-1.5$ & $1.5-3.5$ \\
\hline
\end{tabular}




\begin{tabular}{|c|c|c|c|c|c|c|}
\hline $\begin{array}{l}\text { Surface temperature, } \\
\mathrm{C}^{\circ}\end{array}$ & $6-12$ & - & $12-20$ & $12-19$ & & - \\
\hline Speed of wind, $\%$ & $1-4$ & - & $4-6$ & $4-7$ & & $5-10$ \\
\hline $\begin{array}{l}\text { Intensity of direct } \\
\text { solar radiation, } \%\end{array}$ & - & $20-40$ & $20-40$ & $30-50$ & $20-30$ & - \\
\hline $\begin{array}{l}\text { Relative air } \\
\text { humidity, \% }\end{array}$ & - & $20-100$ & $94-96$ & 95 & 80 & - \\
\hline
\end{tabular}

Table 2 proves, that availability of green planting is capable to regulate the air temperature, intensity of direct solar radiation and relative air humidity.

Ensuring stability of the city as an anthropogenic landscape is the main, but not the only function of the system of the open planted trees and shrubs spaces. Besides, the system promotes the improvement of the urban environment, the creation of conditions for rest of the population, the increase in art expressiveness. Each of these functions separately and all of them together define the form of the system, which can be described as a set of principles of its construction: the interrelation with the landscape fundamentals, continuity, uniformity, multilevel, functional variety, capability to develop, interrelation with the landscape fundamentals, compliance to the environment and features. The principle is first of all directed to the achievement of stability of the urbanized landscape at the expense of the possible share of self-control. The main nature protection actions are reflected in it, including the identification of the kept landscape elements during determination of the optimum use of the territory, recultivation, compensation of violations of the landscape with its improvement (i.e. with the change of the relief and water mode, creation of protective plantings). At the same time these measures, revealing natural features of the territory promote the increase in esthetic expressiveness of the urban environment. Manifestation of such expressiveness is also promoted by small architectural forms, integrated into the park space.

It is also necessary to adhere to the principles of sustainable development of the territories designed to provide the high quality of the urban environment during the organization of public spaces. Providing of high-quality of the urban environment on the example of public open spaces in parks is possible within the implementation of projects of improvement of the park urban areas (city public spaces), based on the following principles:

- The principle of the functional variety - the saturation of territories with various social and commercial facilities.

- The principle of the comfortable organization of the pedestrian environment (creation of conditions for pleasant, safe and convenient pedestrian walks). Attractiveness of pedestrian walks can be provided due to combination of various functions on walking routes. It is expedient to provide various categories of citizens, including to handicapped groups of citizens with the availability of pedestrian walks under various weather conditions.

- The principle of comfortable mobility for the inhabitants (availability of comparable according the speed and level of comfort of opportunities of access to the park zone).

- The principle of the comfortable environment for communication (harmonious and available placement of small architectural forms in the park, as well as other elements of the architectural-andlandscape ensemble). 
- Principle of saturation of public and private spaces with various elements of the environment of various area (green plantings, water objects, etc.). For example, at the device of small architectural forms, such as gazebo, it is necessary to calculate the capacity of each gazebo competently and to observe optimum distance among them, in order to avoid conflict situations of vacationers in the gazebos in the neighbourhood; the environment elements, such as green hedges promote to organize the space and to improve sound insulation.

With respect thereto, the nature similarity of forms of buildings is one of the most effective and interesting methods of mutual integration of the nature and architectural structures (figure 6).

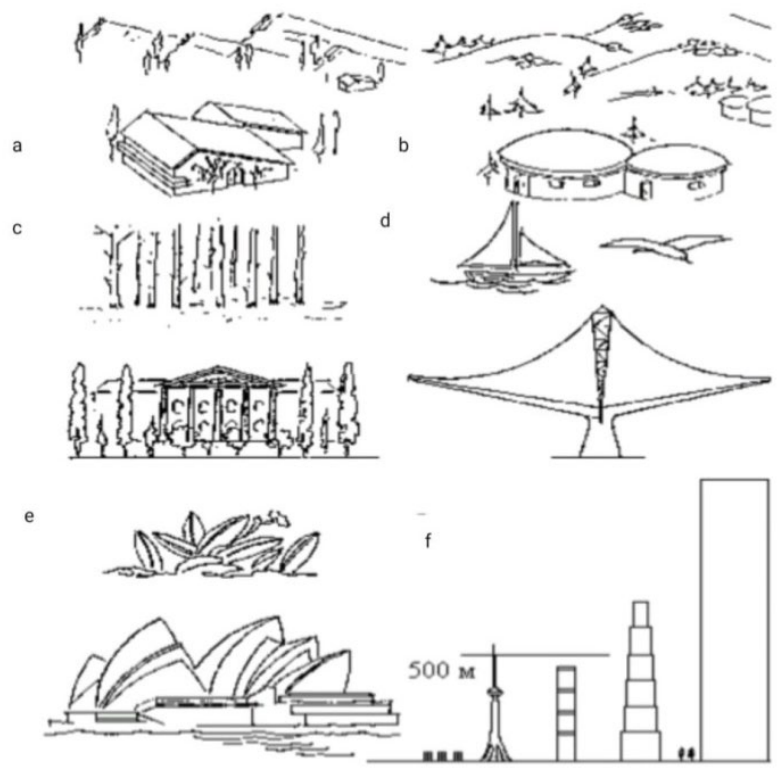

Figure 6. Ilarity of architectural forms

a, b - compliance with the forms of mountains, hills; c - compliance with the shape of trees; d, e compliance with the shapes of the wings, sails, shells; f - buildings and structures that do not correspond to the size and shape of natural objects (two buildings on the right: the figure - in the project; for comparison, tall trees and 3-storey buildings are drawn near the ground) (Khomich, 2002)]

It consists in the imitation of architecture natural forms, therefore there is a symbiosis of urbanization and untouched view of the nature. It is possible to refer to Petaling Jaya Comerical City in Kuala Lumpur, Malaysia sales office and showroom (figure 7) or to the pedestrian bridge in the park Arganzuela, Madrid (figure 7) as examples. 

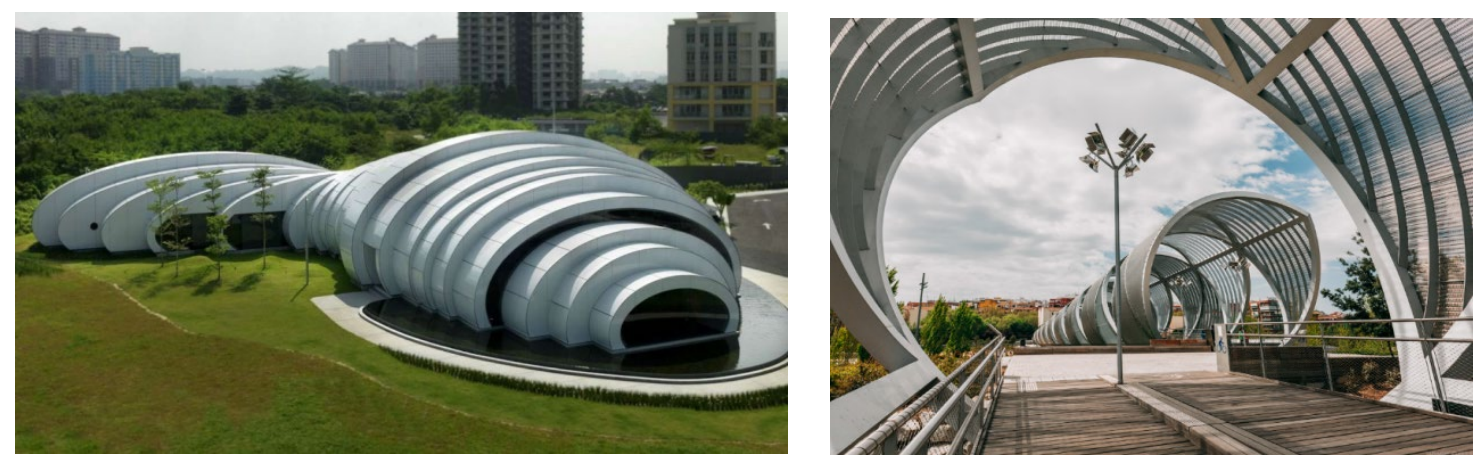

Figure 7. Petaling Jaya Comerical City in Kuala Lumpur, Malaysia is on the left Pedestrian bridge in the park , 2015), pedestrian bridge in Arganzuelapark, Madrid is on the right (Gnatoush, 2015)

\section{Findings}

In 2013 the Northern Tushino park was reconstructed. This modern complex is equipped with beaches, attractions, clubs on interests and entertainments for any taste. Despite modern reconstruction of the park, the shortage of organized spaces for outdoor recreation, such as gazebos and canopies is felt to be considerable. Having carried out the analysis of the necessity of the organization of such places, the authors conclude, that placement of small architectural forms influences the environment of the district positively. Besides there are necessary ecological aspects for the placement of gazebos and improvement of the territory around:

- Placement of trash cans and ballot boxes for waste will help to reduce unauthorized ejection of garbage and to keep the ecosystem of the park. The organized garbage removal is also necessary to avoid the congestion of toxic waste.

- The organization of zones with a brazier promotes visitors of the park not to kindle fire in unauthorized places, as that is the risk of ignition in the green space.

- Great quantity of gazebos in the park reduces the number of visitors who are located in undesirable places; that positively influences the ecology too.

- The guard near the complex of small architectural forms reduces the risk of non-compliance with safety rules in the territory.

- Gazebos in the green space will allow visitors of the park to feel special proximity with the nature.

It is also necessary to adhere to the following criterion of the choice of the gazebos location during the organization of public spaces:

1. Gazebos should be placed in a shadow; they should be turned to the West by their main facade (opened). In the afternoon when the sun shines from the South side, there will be enough shadow, and it will be possible to observe the decline in the evening.

2. Gazebos should be located on the height, in order to avoid dampness, rotting of materials and spring thawing of snow and rain in the summer, if the arbour does not have coastal functionality.

3. It is necessary to construct gazebos not in close contact with forests, in order to avoid ignition. 
4. Regular customers of the park, have usual vacation spots. It is more profitable to build gazebos in those parts for the purpose of ensuring comfort and good attendance.

Having historically developed, the park is divided into five rest areas; that can be seen in figure 8 .

Having analysed all 5 zones of the park, authors of article under placement of small architectural forms chose a northern zone of the park (ECO park) which is intended for rest from daily vanity and the city rhythm of life.

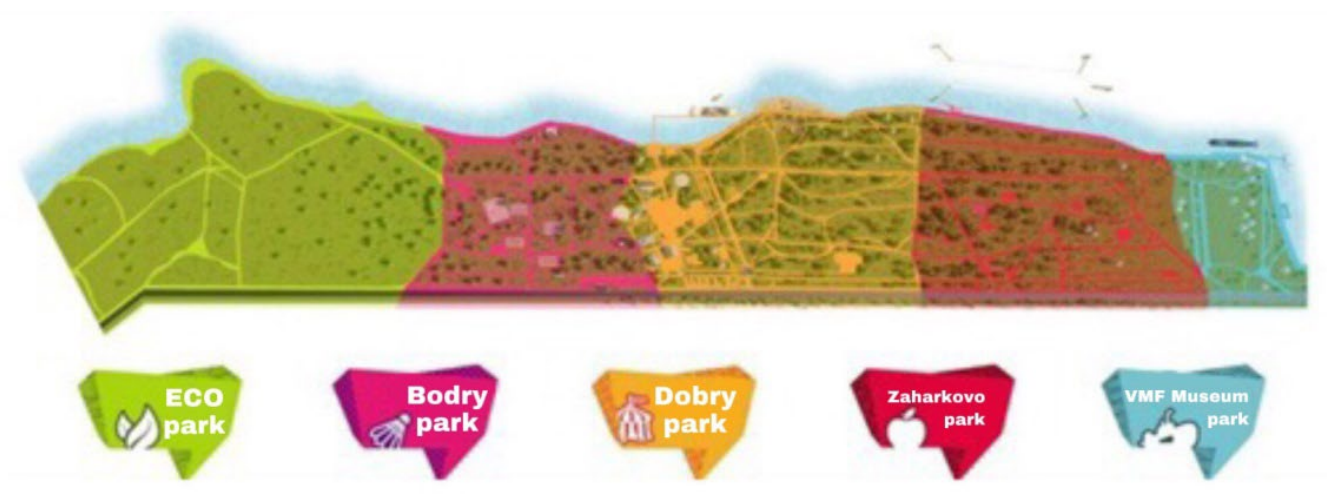

Figure 8. Park zoning (2013)

Its distinctive features are the unique natural landscapes and green plantings unlike other zones. In Eco park the following types of gazebos are suitable for placement best of all:

- Canopy from bad weather. It has the simplest design, often without benches (figure 9).
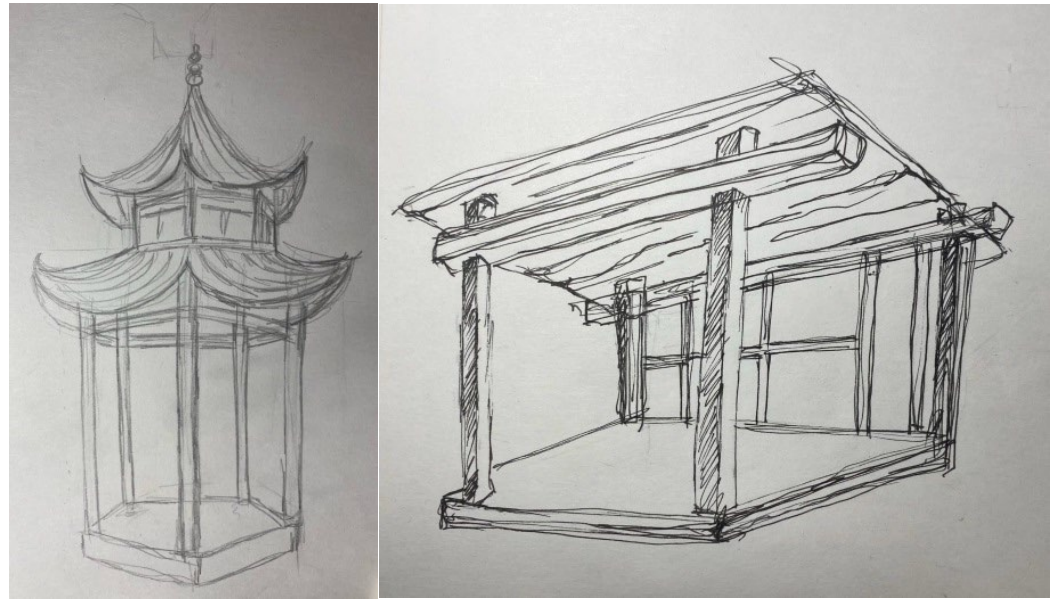

Figure 9. Sketches of gazebos -canopies(compiled by the authors)

- Decorative gazebo. It serves for carrying out time, characterized with the availability of beautiful elements of design, green hedges and a great number of benches (figure 10). 

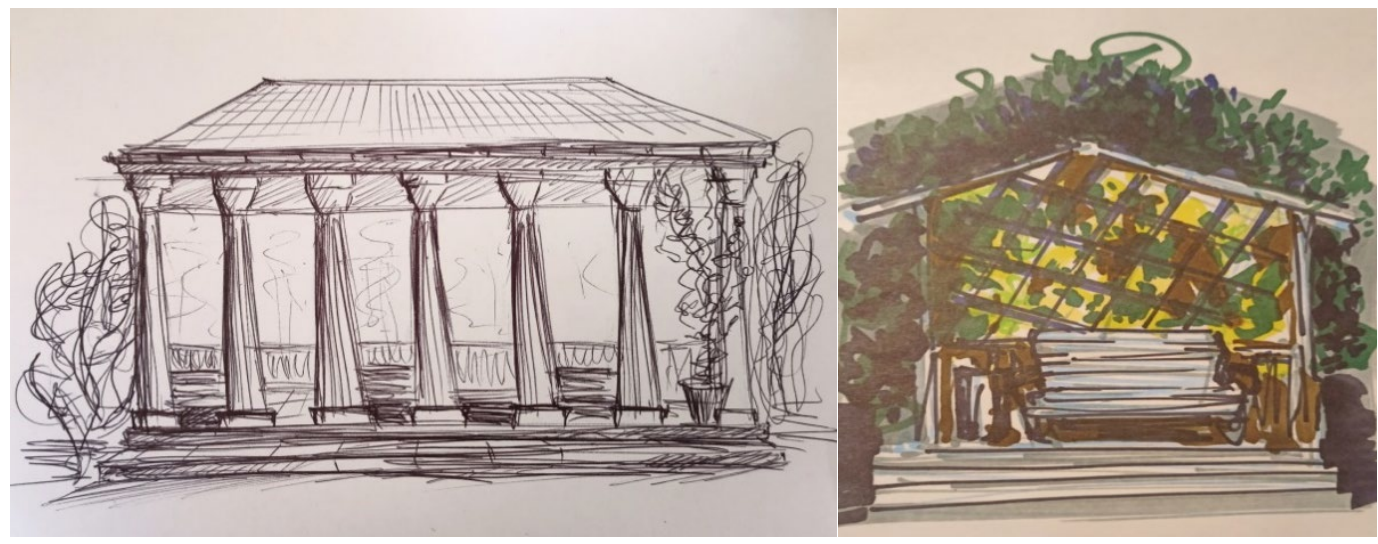

Figure 10. Sketches of decorative gazebos (compiled by the authors)

- Barbecue gazebos. Their distinctive feature are the big sizes; that is caused by the need of placement of rather large number of people, benches and a table, and it has to be made at safe distance from the garden fireplace, a barbecue, a grill, a brazier or the smoking shed which are their integral attribute (figure 11).
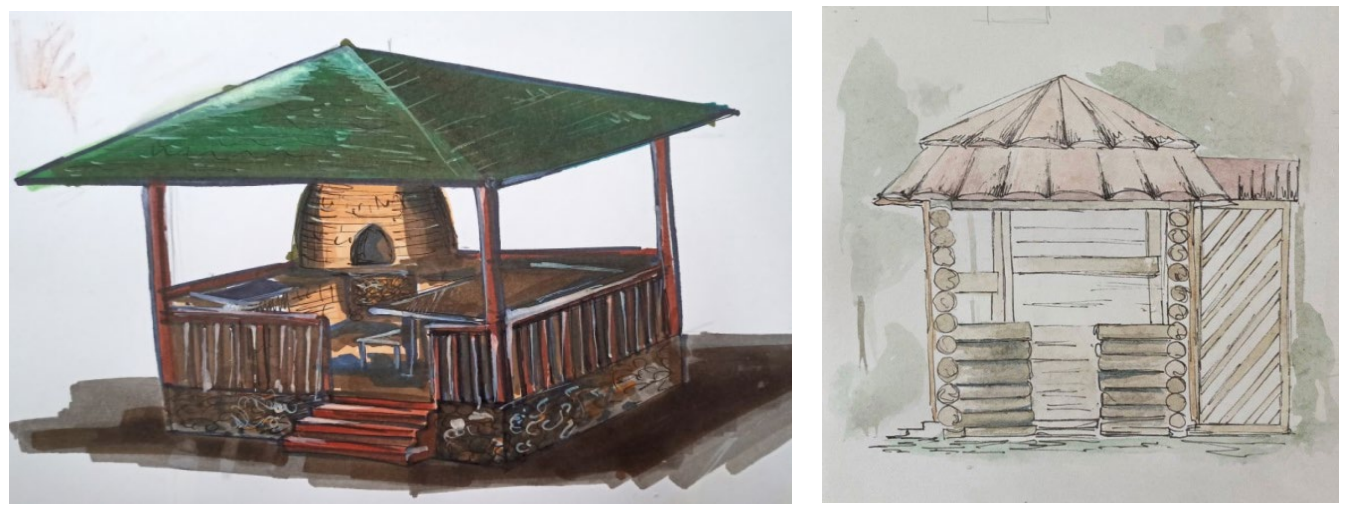

Figure 11. Sketches of barbecue gazebos (compiled by the authors)

Study of the concept of development of gazebos complexes which would include automobile parkings, parking for bicycles and carriages, bathrooms, a small scene for the organization and carrying out holidays, sports and entertaining both playgrounds and small little shop with all necessary for carrying out outdoor recreation is planned in the future.

\section{Conclusion}

The perspective of design and development of public spaces is one of the most popular universal trends in the sphere of city planning today. It is connected with the fact, that public spaces form the city's "face", providing its uniqueness and being responsible for the creation of a harmonious uniform image of the megalopolis. At the same time, when forming of public spaces it is possible to use not only such traditional developed elements as streets, squares, parks, squares, boulevards, embankments, but also the elements, can be conditionally called "alternative", including terraces, gazebos, rest areas of different function, auto-movie-theatres, open scenic areas and so on. 
The role of small architectural constructions in forming of public open spaces on the example of the park Northern Tushino was analysed in this article. The conducted research proved, that architectural forms have a significant role in forming of image of this park and the urban environment in general. The analysis of the small architectural constructions, presented in the form of gazebos and terraces, as well as their groups, revealed the principles of their forming during various historical stages. According to the conducted researches the principles of placement and the sizes of these gazebos are proved and several versions of concepts of gazebos, depending on their functionality, are offered on the example of the park Northern Tushino.

Summing up the results of the aforesaid research it is obvious, that the improvement of public spaces is one of important aspects of city-planning development, which forms the image of the urban environment. On the example of the park Northern Tushino is obvious, that it is not well-planned and demands additional measures for its organization, including some measures, directed both to additional gardening and to the arrangement of additional small architectural structures.

\section{References}

Belvedere Palace in Arkhangelsk. (2021). Great Soviet Encyclopedia. https://dic.academic.ru/dic.nsf/bse/68407/\%D0\%91\%D0\%B5\%D0\%BB\%D1\%8C\%D0\%B2\%D0 $\% \mathrm{~B} 5 \% \mathrm{D} 0 \% \mathrm{~B} 4 \% \mathrm{D} 0 \% \mathrm{~B} 5 \% \mathrm{D} 1 \% 80$

Gazebo-rotunda. (2021). https://pastvu.com/p/568498

Gnatoush, N. (2015, June 15). Madrid, Spain: social - and not only - architecture. [Pedestrian bridge in the park]. https://nessa-flame.blogspot.com/2015/06/trip-madrid-spain.html

Khomich, V. A. (2002). Ecology of the urban environment: Textbook. manual for universities. SibADI Publishing house.

Kurochkina, V. A. (2020a). The impact of long-term construction subjects and industrial areas on the geoecology of cities and development of depressed urban spaces. The Eurasian Scientific Journal, 6(12). https://doi.org/10.15862/36NZVN620

Kurochkina, V. A. (2020b). Water bodies as the basis by open public spaces planning and an instrument of urban transformation. The Eurasian Scientific Journal, 5(12). https://doi.org/10.15862/63SAVN520

Kurochkina, V. A. (2020c). Urban water bodies as the basis for functioning of public spaces. E3S Web of Conferences. Cep. "International Scientific and Practical Conference "Environmental Risks and Safety in Mechanical Engineering", ERSME 2020" 2020. C. 02005.046. https://doi.org/10.1051/e3sconf/202021702005

Kurochkina, V. A. (2020d). Depressed spaces as an instrument for transformation of urban areas.E3S Web of Conferences. Cep. "International Scientific and Practical Conference "Environmental Risks and Safety in Mechanical Engineering", ERSME 2020" 2020. C. 02008. https://doi.org/10.1051/e3sconf/202021702008

Maksimova, O. (2020). What is the ecological framework of the city and why is it needed. https://trends.rbc.ru/trends/green/5ecfa2679a79475081e84b12

Map-diagram of a part of the SevernoyeTushino district with a park. (2021). https://www.google.ru/maps

Mel M. A. Ministry of Construction and Housing and Communal Services of the Russian Federation. Moscow: Order No. 711/ave., 2017

Park zoning. (2013). https://www.m24.ru/articles/blagoustrojstvo/13082013/23391

Pavilion of the Three Graces. (2021). https://pastvu.com/p/131947

Petaling Jaya Comerical City in Kuala Lumpur, Malaysia. (2015). https://nessaflame.blogspot.com/2015/06/trip-madrid-spain.html

The ancient gazebo of Egypt. (2018). https://besedkis.ru/obustrojstvo/raskrytie-termina-besedka 